ISSN: 2224-0616

Int. J . Agril. Res. Innov. \& Tech. 5(2): 31-36, December, 2015 Available online at http://www.ijarit.webs.com

\title{
CHANGES OF ORGANIC PHOSPHORUS IN RIVER WATERS IN NORTHERN BANGLADESH
}

\author{
M.J. Islam ${ }^{*}$, M.S. Rahman', Rubeca Fancy ${ }^{1}$, A.K.M.S. Rahman ${ }^{1}$ \\ M. Shamsuzzoha ${ }^{2}$ and M.A.H. Siddiqi ${ }^{1}$
}

Received 26 August 2015, Revised 29 November 2015, Accepted 22 December 2015, Published online 31 December 2015

\begin{abstract}
The variability in phosphorus concentrations and the decomposition rates of organic phosphorus were measured in five selected rivers through four surveys in July and November of 2012, and February and May of 2013. After collection the water samples were incubated for 20 days in a dark incubator and the change of forms of phosphorus such as particulate organic phosphorus (POP), dissolved organic phosphorus (DOP) and dissolved inorganic phosphorus (DIP) were analyzed. By fitting the changes to two types of models, the decomposition rates of organic phosphorus were determined. The mean total organic phosphorus (TOP) decomposition rate coefficients in the studied rivers was 0.039 day $^{1}$. The average POP decomposition rate coefficient $\left(\mathrm{POP} \rightarrow \mathrm{DOP} \rightarrow \mathrm{DIP}\right.$ model) was 0.038 day $^{1}$ while the mean DOP decomposition rate coefficient was 0.251 day $^{1}$. The decomposition rate coefficients measured in this study might be applicable for modeling of river water quality.
\end{abstract}

Keywords: Organic Phosphorus, Decomposition, River Water

\footnotetext{
${ }^{1}$ Department of Agricultural Chemistry, Hajee Mohammad Danesh Science and Technology University, Dinjapur-5200, Bangladesh

${ }^{2}$ Department of Chemistry, Hajee Mohammad Danesh Science and Technology University, Dinjapur-5200, Bangladesh

*Corresponding author's email: jahidul@hstu.ac.bd (M.J. Islam)
}

\section{Introduction}

A key component in the cycling of organic matter in aquatic ecosystems is decomposition. In aquatic ecosystems, heterotrophic bacteria are primarily responsible for the bulk of decomposition of organic matter (Siuda and Chróst, 2002). However, enzymatic hydrolysis or decomposition is affected by a number of environmental factors, of which temperature, $\mathrm{pH}$ and redox potential are the most important (Reddy and D'Angelo, 1994). Specifically temperature affects the metabolic activity on the decomposing substrate. If nutrients enter as organic matter that first needs to be decomposed before it can be utilized for growth, temperature becomes important due to its effect on the rate of decomposition. In rivers, particulate organic matter (POM) is subjected to different processes such as mineralization, disaggregation and sedimentation that determine its role, behavior and fate in the aquatic ecosystem. However, dissolved organic matter (DOM) consists of a complex mixture of organic compounds where the large majorities (80\%) remain unknown and likely resemble the complex humic compounds found in river water (Stiig Markager et al., 2007). Microbial action not only results in the remineralization of DOM, but also in its transformation in such a way that the DOM pool owes much of its chemical structure to microbial activity. Allochthonous inputs are usually dominated by the refractory component while autochthonous inputs are initially labile becoming refractory over time (Luz et al., 2005).
The rate of decomposition and nutrient release of an organic residue depends on its chemical and biochemical characteristics (Tian et al., 1992; Vanlauwe et al., 1997) referred to as its quality. Generally, residues high in P decompose faster and release more $\mathrm{P}$ within a shorter period (Tian et al., 1992). However, the relative importance of the $\mathrm{P}$ content sometimes depends on the amounts of carbon, lignin, cellulose, polyphenol, nitrogen $\mathrm{N}$ and C:N ratio. For this reason, their ratios to $\mathrm{P}$ are also regarded as predictors of decomposition and $\mathrm{P}$ release. In general, particulate $\mathrm{P}$ is much more variable than dissolved P. Storm events are extremely important for particulate $\mathrm{P}$ dynamics because large portions of annual stream particulate $\mathrm{P}$ loads can be transported attached to sediment and organic matter during only a few major events (Brett et al., 2005). Decomposition of plant detritus involves stepwise conversion of complex organic molecules to simpler organic and inorganic constituents by processes including abiotic leaching (Benner et al., 1985), fragmentation (Boulton and Boon, 1991), extracellular enzymatic hydrolysis (Cunningham and Wetzel, 1989; Linkins et al., 1990), and aerobic and anaerobic catabolic activities of microorganisms (Oremland, 1988; Kerner, 1993). Water temperature is one of the parameters that determine the overall health of aquatic ecosystems (Coutant, 1999). Water temperature has both economic and ecological significance when considering issues such as water quality and biotic conditions in rivers. 
In model calculation of decomposition phenomena, expressions are desired that are realistic in terms of both mathematical and biological behavior. Mathematical models are valuable tools to investigate the biogeochemical mechanisms and their interactions. Modeling the decrease in organic $\mathrm{P}$ concentrations during decomposition process would be of special interest. Interrelationships between different $\mathrm{P}$ fractions contain one or more decomposition rate coefficients that are universal in some senses. However, there is little information available concerning the decomposition rate of organic $\mathrm{P}$ and its related constituents. A reasonable prediction of water quality for the river requires the decomposition rate of organic $\mathrm{P}$ present in the water bodies. Therefore, the objectives of this study were to assess the decomposition rates of organic P thereby influencing $\mathrm{P}$ availability for algal growth in the river water as well as the overall impacts of $\mathrm{P}$ in the river ecosystem.

\section{Materials and Methods}

From five selected rivers representative samples were collected in 20L plastic bottles and were processed for physical, chemical and biological analyses as per standard recommended procedures. The sampling sites of the 5 rivers were the Punarbhaba River (4 sites), the Atrai River (4 sites), the Kharkharia River (4 sites), the Jamuna River(4 sites) and the Tulsi Ganga River (2 sites) of Dinajpur District.

Temperature, $\mathrm{pH}$ and EC were measured in situ with a YSI model 600 multi-parameter water analyzer. Chlorophyll-a concentration was determined by a spectrophotometric method using acetone extraction (Lorenzen, 1967). For the measurements of BOD, sample aliquots were incubated in $300 \mathrm{ml}$ glass BOD bottles at $20{ }^{\circ} \mathrm{C}$ for 5 days in the dark. Dissolved oxygen (DO) was measured by DO meter. For $\mathrm{COD}_{\mathrm{Mn}}$, samples (30 ml) were treated with $5 \mathrm{mN} \mathrm{KMnO}_{4}$ in $1 \% \mathrm{NaOH}$ for 1 hour at $100{ }^{\circ} \mathrm{C}$ in an autoclave. Total phosphorus (TP) concentration was determined by persulfate digestion followed by the ascorbic acid method for ortho-phosphate analysis. Total nitrogen (TN) was determined by auto analyzer (SKALAR 5100) employing Cd reduction column after decomposing sample by persulfate digestion. Nitrate was determined by $\mathrm{Cd}$ reduction method (APHA, 2005). Water samples were incubated for 20 days in a dark incubator and the change of forms of phosphorus such as particulate organic phosphorus (POP), dissolved organic phosphorus (DOP) and dissolved inorganic phosphorus (DIP) were analyzed. By fitting the change to two types of models the decomposition rates of organic phosphorus were determined. The total organic phosphorus (TOP) decomposition rate coefficient indicates combined overall decomposition rate coefficients of POP and DOP. Within the models, it is assumed that conversion of POP and DOP to phosphate proceeds through hydrolysis and mineralization. Decomposition rates of organic phosphorus were measured at $0,1,2,3,5,7,10$, 15 and 20 days after beginning of incubation at $20^{\circ} \mathrm{C}$. The DIP (dissolved inorganic P), DTP (dissolved total $\mathrm{P}$ ) and TP (total P) concentrations of the water samples were measured for $\mathrm{P}$ content. The dissolved and particulate fractions are usually distinguished by filtration through a $0.45-\mu \mathrm{m}$ membrane that separates most bacteria, algae and mineral particles from the dissolved phase but fails to separate colloidal particles. The DIP was analyzed after $\mathrm{GF} / \mathrm{F}$ filtration $(0.45 \mu \mathrm{m})$ by applying the molybdenum blue method at 880 $\mathrm{nm}$, according to the American Public Health Association (APHA, 2005). The DTP was estimated from the filtered sample as the DIP after persulfate digestion (APHA, 2005). The DOP was obtained by subtracting the DIP from the DTP. The TP was analyzed from the unfiltered sample as the DIP after persulfate digestion and determined after the Mo-blue method, according to APHA (2005).

In this study the following four different models were employed for simulating phosphorus cycle in river water. Each decay model was fitted to the data collected from incubation experiment and rate coefficients were determined by optimization. The determinations of coefficients were performed by iterative Runge-Kutta method programmed on EXCEL spreadsheet (Brezonik, 1994). The time step for iterative integration was set to 0.1 day.

Model 1; Total organic phosphorus $\rightarrow$ dissolved inorganic phosphorus (DIP)

$$
\frac{d(T O P)}{d t}=-k_{T O P}(T O P)
$$

Where,

$\mathrm{TOP}=$ Total organic phosphorus concentration $k_{\text {TOP }}=$ TOP decomposition rate coefficient [ day ${ }^{-1}$ ] $\mathrm{t}=$ decomposition time [day]

Model 2: Particulate organic P (POP) $\rightarrow$ dissolved organic $\mathrm{P}(\mathrm{DOP}) \rightarrow$ dissolved inorganic P (DIP)

$$
\begin{aligned}
& \mathrm{k}_{\mathrm{POP}} \quad \mathrm{k}_{\mathrm{DOP}} \\
& \mathrm{POP} \rightarrow \mathrm{DOP} \rightarrow \mathrm{DIP} \\
& \frac{d(P O P)}{d t}=-k_{P O P}(P O P) \\
& \frac{d(D O P)}{d t}=k_{P O P}(P O P)-k_{D O P}(D O P) \ldots \ldots \ldots . .(3) \\
& \frac{d(D I P)}{d t}=k_{D O P}(D O P)
\end{aligned}
$$

In this model, organic $\mathrm{P}$ was divided into POP and DOP. The basic concept of this model is that during the decomposition process, $\mathrm{POP}$ is first converted into DOP and then DOP is transformed into DIP or SRP (soluble reactive P). 


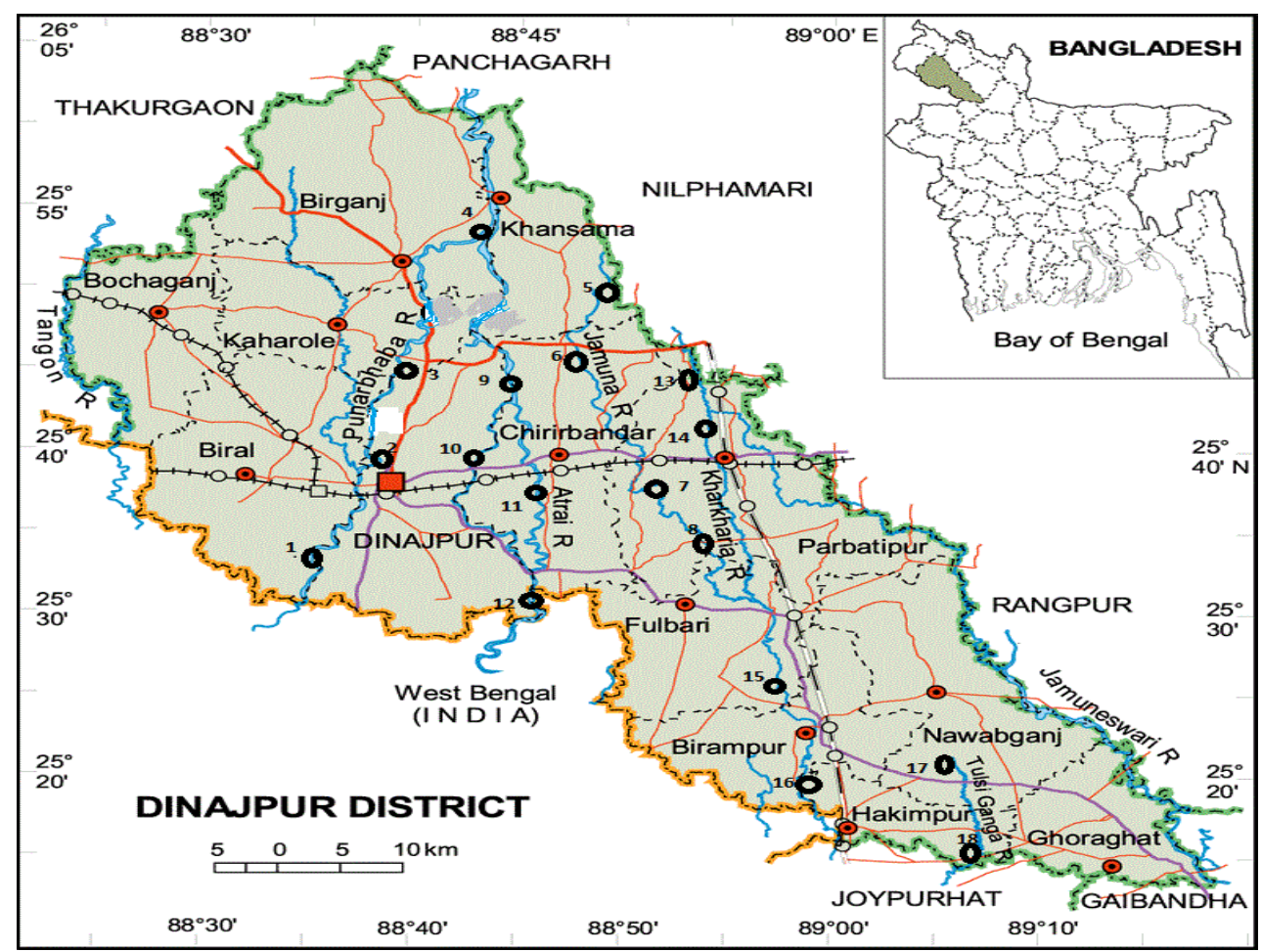

Fig.1. Map of the sampling sites of the 5 rivers (Punarbhaba River- 4 sites, Atrai River-4 sites, Kharkharia River - 4 sites, J amuna River-4 sites and Tulsi Ganga River-2 sites) of Dinajpur District.

\section{Results and Discussion}

Figure 1 shows the different sampling sites of the 5 rivers of Dinajpur. For the measurement of the decomposition coefficient of organic phosphorus through $\mathrm{POP} \rightarrow \mathrm{DOP} \rightarrow \mathrm{DIP}$ model, a typical example of sample number 18 is shown in Figure 2 . The $\mathrm{pH}$ of all the rivers ranged from $6.3 \sim 6.9$ with a mean of 6.6 (Table 1). However, the differences of $\mathrm{pH}$ among the samples collected at each site were relatively small. Differences in the decomposition rates could be due to differences in water chemistry $(\mathrm{pH}$, alkalinity, nutrient concentrations). Higher breakdown rates of organic matter have been described before in alkaline systems in comparison with more acidic ones (Chamier, 1992). In reflective of the extent of ion strengths, EC increased by several folds

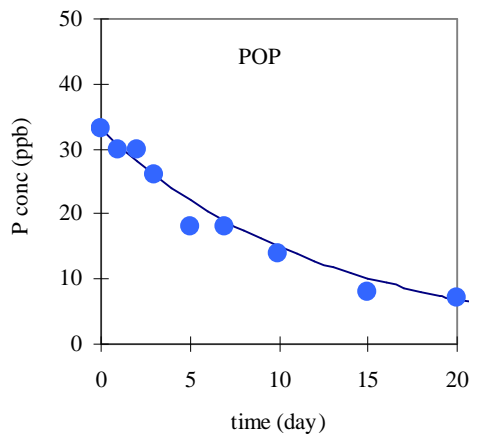

along the river line, with its values being obviously smaller for samples at lower flow rate and water levels. However, the mean value of EC of all the rivers was $192 \mu \mathrm{S} / \mathrm{cm}$. The average DO value was $8.3 \mathrm{mg} \mathrm{O} / \mathrm{L}$. The COD, an index of BOD is inversely proportional to DO. Consequently, the higher the value of $\mathrm{DO}$, the lower the level of COD and BOD were observed in the waters. Actual nutrients and energy requirement strongly affects the synthesis rates, structure and efficiency of microbial ectoenzymes. The resultant activity of ectoenzymes determines the sequence and rates of utilization of various DOM and POM constituents by microorganisms (Siuda and Chróst, 2002). The average concentration of $\mathrm{NO}_{3}$ of the study river $1.1 \mathrm{mg} / \mathrm{L}$.

Fig 2. An example (sample no. 18) of the changes of particulate organic phosphorus (POP), dissolved organic phosphorus (DOP) and dissolved inorganic (DIP) concentration using POP-DOP-DIP model. 
Table 1. Water quality characteristics of the selected rivers in northern Bangladesh

\begin{tabular}{lccccc}
\hline Parameters & J uly, 12 & Nov, 12 & Feb, 13 & May,13 & Mean \\
\hline Temperature $\left({ }^{0} \mathrm{C}\right)$ & 22.0 & 18.0 & 24.0 & 27.0 & 22.8 \\
$\mathrm{pH}$ & 6.7 & 6.9 & 6.5 & 6.3 & 6.6 \\
$\mathrm{EC}(\mu \mathrm{S} / \mathrm{cm})$ & 255 & 150 & 175 & 190 & 192 \\
$\mathrm{DO}\left(\mathrm{mgO}_{2} / \mathrm{L}\right)$ & 9.8 & 8.7 & 7.0 & 7.8 & 8.3 \\
$\mathrm{BOD}\left(\mathrm{mgO}_{2} / \mathrm{L}\right)$ & 1.6 & 1.1 & 1.3 & 2.1 & 1.5 \\
CODMn $\left(\mathrm{mgO}_{2} / \mathrm{L}\right)$ & 3.5 & 5.5 & 6.5 & 7.2 & 5.7 \\
$\mathrm{Chlorophyll} \mathrm{a}\left(\mathrm{mg} / \mathrm{m}^{3}\right)$ & 21 & 11 & 17.0 & 28.0 & 19.1 \\
$\mathrm{TN}(\mathrm{mg} / \mathrm{L})$ & 2.58 & 1.00 & 3.1 & 4.6 & 2.8 \\
$\mathrm{NO}_{3}(\mathrm{mg} / \mathrm{L})$ & 1.33 & 0.39 & 0.8 & 1.98 & 1.1 \\
\hline
\end{tabular}

Table 2. TOP decomposition rates ( $\mathrm{k}_{\mathrm{TOP}}$ ) of the selected rivers in northern Bangladesh

\begin{tabular}{|c|c|c|c|c|c|c|}
\hline \multirow[t]{2}{*}{ Rivers } & \multirow{2}{*}{$\begin{array}{c}\text { Sampling site } \\
\text { no. }\end{array}$} & \multicolumn{4}{|c|}{ Sampling dates and values } & \multirow[t]{2}{*}{ Mean } \\
\hline & & July, 12 & Nov, 12 & Feb, 13 & May,13 & \\
\hline & 1 & 0.078 & 0.062 & 0.065 & 0.069 & 0.069 \\
\hline \multirow[t]{2}{*}{ Punarbhaba } & 2 & 0.082 & 0.032 & 0.045 & 0.055 & 0.054 \\
\hline & 3 & 0.045 & 0.029 & 0.032 & 0.041 & 0.037 \\
\hline & 4 & 0.063 & 0.028 & 0.043 & 0.048 & 0.046 \\
\hline \multirow[t]{4}{*}{ Jamuna } & 5 & 0.042 & 0.031 & 0.028 & 0.037 & 0.035 \\
\hline & 6 & 0.046 & 0.023 & 0.036 & 0.043 & 0.037 \\
\hline & 7 & 0.047 & 0.045 & 0.033 & 0.041 & 0.042 \\
\hline & 8 & 0.025 & 0.021 & 0.027 & 0.029 & 0.026 \\
\hline \multirow[t]{4}{*}{ Atari River } & 9 & 0.054 & 0.028 & 0.034 & 0.044 & 0.040 \\
\hline & 10 & 0.03 & 0.018 & 0.026 & 0.029 & 0.026 \\
\hline & 11 & 0.029 & 0.025 & 0.031 & 0.037 & 0.031 \\
\hline & 12 & 0.064 & 0.055 & 0.039 & 0.048 & 0.052 \\
\hline \multirow[t]{4}{*}{ Kharkharia } & 13 & 0.049 & 0.032 & 0.031 & 0.042 & 0.039 \\
\hline & 14 & 0.043 & 0.014 & 0.028 & 0.037 & 0.031 \\
\hline & 15 & 0.023 & 0.009 & 0.024 & 0.032 & 0.022 \\
\hline & 16 & 0.019 & 0.013 & 0.021 & 0.027 & 0.020 \\
\hline \multirow[t]{2}{*}{ Tulsi Ganga } & 17 & 0.048 & 0.032 & 0.039 & 0.045 & 0.041 \\
\hline & 18 & 0.075 & 0.066 & 0.059 & 0.061 & 0.065 \\
\hline Mean & & 0.048 & 0.031 & 0.036 & 0.043 & 0.039 \\
\hline SD & & 0.019 & 0.016 & 0.012 & 0.011 & 0.014 \\
\hline
\end{tabular}

Table 3. POP decomposition rates ( $\mathrm{k}_{\mathrm{POP}}$ ) of the selected rivers in northern Bangladesh

\begin{tabular}{lcccccc}
\hline Rivers & Sampling & \multicolumn{4}{c}{ Sampling dates and values } & Mean \\
\cline { 2 - 6 } & site no. & July, 12 & Nov, 12 & Feb, 13 & May, 13 & \\
\hline \multirow{3}{*}{ Punarbhaba } & 1 & 0.064 & 0.024 & 0.031 & 0.038 & 0.039 \\
& 2 & 0.066 & 0.014 & 0.024 & 0.035 & 0.035 \\
Jamuna & 3 & 0.034 & 0.025 & 0.025 & 0.029 & 0.028 \\
& 4 & 0.026 & 0.025 & 0.021 & 0.034 & 0.027 \\
& 5 & 0.031 & 0.029 & 0.034 & 0.045 & 0.035 \\
& 6 & 0.048 & 0.025 & 0.031 & 0.045 & 0.037 \\
Atari & 7 & 0.065 & 0.062 & 0.055 & 0.069 & 0.063 \\
& 8 & 0.025 & 0.028 & 0.034 & 0.044 & 0.033 \\
& 9 & 0.045 & 0.029 & 0.031 & 0.042 & 0.037 \\
Kharkharia & 10 & 0.048 & 0.031 & 0.027 & 0.037 & 0.036 \\
& 11 & 0.052 & 0.062 & 0.042 & 0.045 & 0.050 \\
& 12 & 0.045 & 0.022 & 0.028 & 0.046 & 0.035 \\
Tulsi Ganga & 13 & 0.042 & 0.049 & 0.035 & 0.042 & 0.042 \\
& 14 & 0.061 & 0.023 & 0.028 & 0.045 & 0.039 \\
Mean & 15 & 0.009 & 0.006 & 0.021 & 0.032 & 0.017 \\
SD & 16 & 0.043 & 0.035 & 0.028 & 0.039 & 0.036 \\
& 17 & 0.048 & 0.032 & 0.031 & 0.045 & 0.039 \\
& 18 & 0.09 & 0.047 & 0.042 & 0.052 & 0.058 \\
\hline
\end{tabular}


Table 4. DOP decomposition rates ( $\mathrm{k}_{\mathrm{DOP}}$ ) of the selected rivers in northern Bangladesh

\begin{tabular}{lcccccc}
\hline Rivers & Sampling & \multicolumn{4}{c}{ Sampling dates and values } & Mean \\
\cline { 3 - 5 } & site no. & July, 12 & Nov, 12 & Feb, 13 & May,13 & 0.318 \\
Punarbhaba & 1 & 0.291 & 0.500 & 0.235 & 0.245 & 0.255 \\
& 2 & 0.328 & 0.225 & 0.214 & 0.254 & 0.256 \\
Jamuna & 3 & 0.43 & 0.175 & 0.185 & 0.232 & 0.181 \\
& 4 & 0.152 & 0.101 & 0.255 & 0.214 & 0.160 \\
& 5 & 0.18 & 0.118 & 0.155 & 0.185 & 0.293 \\
Atari & 6 & 0.245 & 0.399 & 0.245 & 0.282 & 0.250 \\
& 7 & 0.193 & 0.298 & 0.245 & 0.265 & 0.202 \\
& 8 & 0.281 & 0.133 & 0.174 & 0.219 & 0.264 \\
Kharkharia & 9 & 0.263 & 0.244 & 0.265 & 0.284 & 0.257 \\
& 10 & 0.223 & 0.254 & 0.264 & 0.285 & 0.193 \\
& 11 & 0.216 & 0.100 & 0.219 & 0.235 & 0.267 \\
Tulsi Ganga & 12 & 0.300 & 0.239 & 0.254 & 0.275 & 0.246 \\
& 13 & 0.224 & 0.244 & 0.250 & 0.265 & 0.231 \\
Mean & 14 & 0.295 & 0.183 & 0.211 & 0.234 & 0.160 \\
\hline SD & 15 & 0.151 & 0.104 & 0.185 & 0.198 & 0.342 \\
\hline
\end{tabular}

In the Model 1, the mean TOP decomposition rate coefficients of the study rivers was 0.039 day- $^{-1}$ (Table 2). The average POP decomposition rate coefficients of $\mathrm{POP} \rightarrow \mathrm{DOP} \rightarrow \mathrm{DIP}$ model was 0.038 day $^{-1}$ (Table 3) while the mean DOP decomposition rate coefficients was 0.251 day $^{-1}$ (Table 4). The decomposition of the TOP, POP and DOP behaved nonlinearly as far as their stabilities in aquatic environment. Differences in overall decomposition rate of organic $\mathrm{P}$ were attributed to differences in the relative proportions of the labile and recalcitrant fractions initially present in each water sample. However, the modeled concentrations of DIP, DTP and TP were consistent with the experimental results, although a little variation was observed in case of highly polluted water samples.

Although we did not measure the enzyme activities, the basis of the organic $\mathrm{P}$ decomposition processes is almost entirely the enzymatic which was excreted by different microorganisms in aquatic environment. Organic $\mathrm{P}$ compounds must first be converted to DIP for utilization by bacteria and phytoplankton (Ammerman and Azam, 1985), thus the structural character of DOP influences its bioavailability. Although the phytoplankton is also capable of assimilating $\mathrm{P}$ from the $\mathrm{POP}$ (Cembella et al., 1984) and DOP (Cotner and Wetzel, 1992), however, the bioavailability of DOP may be reduced if it is associated with humic acids (Reynolds and Davies, 2001). As decomposition proceeds, soluble components and relatively easily degraded compounds such as sugar, starches and proteins will be rapidly utilized by decomposers, while more recalcitrant materials such as cellulose, fats, tannins and lignins will be decomposed at relatively slower rates. Thus, with time, the relative proportion of these recalcitrant materials will progressively increase and the decomposition rate might decrease in the later stage of decomposition. However, in this study labile OP and recalcitrant OP were not discriminated, because it might have increased errors with exponential decrease model.

There was a difference in the decomposition rates under constant temperature perhaps due to aerobic and anaerobic conditions. Although a more complex model equation including microorganisms, $\mathrm{pH}$, and redox potential may be able to improve the reproduction of real systems, it has been argued that increasing the number of parameters and complexity of the model will lead to an increase in model uncertainty as well as less accurate decomposition coefficient. The results indicate that the calibration results are quite acceptable. Conducting decomposition experiments at constant temperature and $\mathrm{pH}$ for a prolonged period would be very helpful to determine the extent of potential mineralization that can be induced by changes in stressors' levels due to hydro-climatic changes. The data obtained from such task should further aid to estimate P stability in rivers that in turn, assist to devise appropriate strategies to reduce the $\mathrm{P}$ mobility in the ecosystem. The decomposition rate coefficients measured in this study might be applicable for modeling of river water quality.

\section{Conclusion}

Even though there was a little difference in the decomposition rates under constant temperature 
perhaps due to aerobic and anaerobic conditions; in most cases, the data were well fitted with the model simulation. We believe that every modelwhether it relies on a simple conceptual or a fully mechanistic approach will certainly run into the limits if other factors of decomposition go down to a level where distinct changes in the overall structure of the ecosystem appear. The model equations employed here lend themselves well to determining the rate of decomposition of organic $\mathrm{P}$ because it makes no assumptions what microorganisms are involved in the decomposition process. This study suggests that the respective decomposition rate coefficients are fairly constant. The decomposition coefficients measured in this study would obviously give a guideline to the selection of parameters in modeling the river water quality.

\section{Acknowledgement}

The authors are grateful to the University Grants Commission, Bangladesh for providing the financial support to conduct this research.

\section{References}

Ammerman, J.W. and Azam, F. 1985. Bacterial 5nucleotidase in aquatic ecosystems: A novel mechanism of phosphorus regeneration. Sci. 227: 1338-1340.

APHA (American Public Health Association). 2005. Standard Methods for the Examination of Water and Wastewater, 21th ed. American Public Health Association, Washington DC. pp. 3-103.

Benner, R.M., Moran, M.A. and Hodson, R.E. 1985. Effects of $\mathrm{pH}$ and plant source on lignocellulose biodegradation rate in two wetland ecosystems, the Okeefenokee Swamp and a Georgia salt marsh. Limnol. Oceanogr. 30: 489-499.

Boulton, A.J. and Boon, P.I. 1991. A review of methodology used to measure leaf litter decomposition in lotic environments: Time to turn over an old leaf. Australian J. Marine \& Freshwater Res. 42: 1-43.

Brett, M.T., Arhonditsis, G.B., Mueller, S.E., Hartley, D.M., Frodge, J.D. and Funke, D.E. 2005. Non-point source nutrient impacts on stream nutrient and sediment concentrations along a forest to urban gradient. Environ. Manage. 35: 330-342.

Brezonik, P.L. 1994. Chemical Kinetics and Process Dynamics in Aquatic Systems. Lewis Publishers, USA. pp. 25-107.

Cembella, A.D., Anita, N.J. and Harrison, P.J 1984. The utilization of inorganic and organic phosphorus compounds nutrients by eukaryotic microalgae-a multidisciplinary perspective. Part 1, Crit. Rev. Microbiol. 10: 317-391.

Chamier, A.C. 1992. Water Chemistry. In: Barlocher, F. (ed.) The Ecology of Aquatic Hyphomycetes, Springer-Verlag, Berlin. pp. 152-172.

Cotner, J.B. and Wetzel, R. 1992. Uptake of dissolved inorganic and organic phosphorus compounds by phytoplankton and bacterioplankton. Limnol. Oceanogr. 37: 232-243.

Coutant, C.C. 1999. Perspectives on temperaturein the Pacific Northwest's fresh waters.Environmental Sciences Division, Publication No. 4849. Oak Ridge National Laboratory.pp. 108.

Cunningham, H.W. and Wetzel, R.G. 1989. Kinetic analysis of protein degradation by a freshwater wetland sediment community. Appl. Environ. Microbiol. 56: 1963-1976.

Kerner, M. 1993. Coupling of microbial fermentation and respiration processes in an intertidal mudflat of the Elbe estuary. Limnol. Oceanogr. 38: 314-330.

Linkins, A.E., Sinsabaugh, R.L., McClaugherty, C.A. and Melills, J.M. 1990. Cellulase activity on decomposing leaf litter in microcosms. Plant and Soil 123: 17-25.

Lorenzen, C.J. 1967. Determination of chlorophyl and pheo-pigments. Spectrophotometric equation. Limnol. Oceanogr. 12: 343-346.

Luz, M., Romero, Thomas J. Smith Iii and James W. Fourqurean. 2005. Changes in mass and nutrient content of wood during decomposition in a south Florida mangrove forest. J . Ecol. 93: 618- 631.

Oremland, R.S. 1988. Biogeochemistry of methanogenic bacteria. In: Zender, A.J.B. (ed.), Biology of Anaerobic Microorganisms, J ohn Wiley \& Sons, NY. pp. 641-707.

Reddy, K.R. and D'Angelo, E.M. 1994. Soil Processing and regulating water quality in wetlands. In: W.J. Mitsch (ed.) Global wetlands old world and new. Elsevier. pp. 309-324.

Reynolds, C.S. and Davies, P.S. 2001. Sources and bioavailability of phosphorus fractions in freshwaters: a British perspective. Biol. Rev. Camb. Philos. Soc. 76: 27-64.

Siuda, W. and Chróst, R.J. 2002. Decomposition and utilization of particulate organic matter by bacteria in lakes of different trophic status. Polish J. Environ. Studies 11: 53-65.

Stiig Markager, Morten Søndergaard, Mathias Middelboe and Colin Stedmon. 2007. A global perspective on dissolved organic matter and the world's smallest organisms. A project on the GALATHEA3 cruise. Partially funded by the Danish Research Council. 750p.

Tian, G., Kang, B.T. and Brussaard, L. 1992. Biological effects of plant residues with contrasting chemical composition under humid tropical conditions - decomposition and nutrient release. Soil Biol. Biochem. 24: 1051-1060.

Vanlauwe, B., Diels, J., Sanginga, N. and Merckx, R. 1997. Residue quality and decomposition: an unsteady relationship? In: Cadisch, G. and Giller, K.E. (Eds.), Driven by nature: plant litter quality and decomposition. $\mathrm{CAB}$ International. pp. 157-166. 